\title{
Development of rural non-importables for the development of rural agribusiness to boost regional economy
}

\author{
Igor Aleksandrov ${ }^{1, *}$, and Marina Fedorova ${ }^{2}$ \\ ${ }^{1}$ Peter the Great St.Petersburg Polytechnic University, Polytechnicheskaya 29, 195251, St. \\ Petersburg, Russia \\ ${ }^{2}$ Petrozavodsk State University, Lenina 33, 185910, Petrozavodsk, Russia
}

\begin{abstract}
The main aim of the research is to propose options for nonimportables producing at rural territories to boost the development of agribusiness. One of the most possible and promising non-importable to be developed and which ensures sustainability is rural and ecotourism. We revised the development of Russian tourism with the help of statistical data and used the regressions method for different periods of time to understand whether the process was stable and positive. Another goal was to estimate whether the government procedures play real efficient role in the development of tourism industry of tourist destinations of the North Western Federal District, or the bottom up development is more appropriate for little tourist destinations. To analyze this hypothesis the tourism development from 2006 to 2016 in the regions the Northwestern Federal District was revised. The methods of theoretical research come from the analysis of theoretical research on the subject. The methods of empirical research are based on comparison, analogy and generalizations according to statistic and other official data.
\end{abstract}

\section{Introduction}

As ascertain Krutikov V. et al. [1] Russia possesses vast territories of rural territories with great entrepreneur potential which is not realized to great extent, due to a plethora of bureaucratic, institutional, mental and even geographical obstacles. According to Fedorova $\mathrm{M} . \mathrm{Yu}$. [2] at the present time entrepreneurship could be the great opportunity for locals to raise their level of life, to struggle with unemployment and poverty. $40 \%$ of poor people of Russia live in the countryside. New opportunities of digital era and post-modern economy gives new chances to rural territories to be developed according its own sustainable ways.

Nevertheless, we assume the bottom up development as the most appropriate for rural areas, the importance of planning and management should not be underestimated in a view of environment and culture sustainability. That is why we propose rural tourism as a possible way to produce non-importables on a territory. So the objective of the paper is to

\footnotetext{
* Corresponding author: a7830298@ gmail.com
} 
find out which is the role of government in rural tourism development as a tool for development of municipalities and hence regional economics at its whole.

Taking into account the hypothesis of Hall C. et al [3] and Akimova L. E. Volkov S. K. [4] that tourism destination with only one element dominating will face problems competing with other tourism destinations which try to use all resources they possess, we are sure that creating a competitive tourism destination at the territory of the countryside is long-overdue not only because of tourism development importance, but as an important component for the development of the whole territory, as far as the main components of tourism infrastructure arrange the whole infrastructure of a territory, which provides the high quality of life for locals.

\section{Literature Review}

Talking about rural tourism development and creating a little rural tourism destination which is considered to be as a complex one, proposed by Levin [5] does not work at the majority of tourist destinations of Russia, there is no interacting element inside, neither relations between them, but we observe a large number of tourists and strong demand for tourism services. As well, the postulate that governance system provides the mechanism to adapt and to change and maintain integrity and function [6] does not work in Russia also.

Even if we take into account the first stage of a tourist destination development proposed by Butler [7], the possibility to allow key stakeholders of a rural destination to develop according to the principles of sustainability and to become "the core of the network, and form an elite", noted by Cooper et al. [8] also does not work in Russia, because the mentality of rural territories appeals to equality due to the history of USSR and so on, and the conviction that the whole responsibility to make village flourish is on its authority, as it ascertain Stylidis D. [9].

The main purpose of the governance of any socio-economic system as a tourist destination, and a rural tourism destination also, is to improve capabilities for selforganization and to build capacity for learning and adaptation, but not to forestall its evolutional stages [5], in such a way it will be quiet resilient to internal and external shocks.

We also have to remember that, the perception by locals of their territory plays a great role in support of tourism development at whole, as it is ascertained by Schroeder T. [10], Ramkissoon H, Nunkoo R. [11], Ahmetov V. Ya., [12], and it raises the motivation to become an entrepreneur. According to the interviews implemented by the Russian Public Opinion Research Center the life in the countryside gets worse.

That is why bottom-up development or endogenous development for rural territories looks like as a very attractive and viable one. But the majority of Russian and foreign researches Nefyodova T.G., Pallot J., [13], Nefyodova T.G. [14], Gagarsky M.D. [15], Wang Z.[16] agree that nowadays locals of the countryside do not participate nor social neither economic changing of a territory, but prefer just to contemplate; there is also nor cooperating neither networking among locals and it prevents any positive changing. Talking about self-organization we also have to remember about its influence on the community of the countryside and on the environment, both of them not always positive without adequate planning and management, mentioned by Alekseeva N.D. [17].

As to the development of tourism in Russia, evidently, in the times of serfdom, tour services were used mainly by nobles. The nobles were owners of vast rural territories and the term "rural tourism" was not widespread, due to the fact that wealthy people had their estates in the countryside and spent there the whole year or different periods of time.

According to Alekseeva N.D. [17], we can see the role of government in tourism development in Russia in the $30 \mathrm{~s}$ of the XX century outstanding workers and representatives of political and cultural elites were encouraged by tour packages to river 
cruises. From the $50 \mathrm{~s}$ of the $\mathrm{XX}$ century river cruises became the recreational type of tourism for the masses. The monopoly tour operator "Intourist" was created in 1929. We see the increase in tourism development in USSR from 50s of the XX century not only in river cruises, but also in trekking, family beach tours, active tours down the rivers, horse tours, vacation in childrens' camps. The regional tourism was in priority, hence, plenty of campings, tour bases, points of tourism equipments' rent. As Douglas C. Frechtling, assumes [18] during the period of 70-80 of the XX century more than 30 million of the population of USSR participated in different active tours. For the reason of the "iron curtain" the population of the USSR traveled only inside the USSR and near abroad countries.

The period after the "perestroika" reasoned the decrease in demand for tourism service due to breakthrough of prices for tour packages. At the same time the tour agency "Intourist" is not a monopolist now, new competitive tour operator and agencies come to the market, no more "iron curtain", and gradually with the rise of incomes the population starts travelling outside the boundaries of the Russian Federation. Because of the fact that tour packages to Turkey and Egypt were quiet affordable for the Russian population at this time, tourism superstructure began to degrade and the quality of Russian service due to its historical monopoly was too low, tour packages outside the boundaries of Russian became more competitive.

The first decree to develop the legislative base of tourism and to designate its role in the economics of the country was enacted in 1994. This decree prescribed to provide all possible support of tourism development in the Russian Federation. Federal law "Bases for Tourism Industry Activity" enacted in 1996 prescribed the terms of tourism industry, principles of state governance of tourism industry and pointed the priority of tourism development in the Russian Federation once again.

As Alekseeva N.D. ascertain [17], the retrospective review of the tourism development in Russia shows that active and nature-oriented types of tourism with the use of ecological types of transport were always in demand in Russia. Due to the historical perturbations of Russia the legislative and technical bases, as far as the standards of services are mainly at their dawn. During the whole period of historical development of the tourism, it balanced from one to the other extreme, there were trips affordable only for a handful of wealthy people, or it turned into mass tourism, it did not evaluated with passing all its stages as it was in Europe and America. Protection the environment was not in priority neither during the period of elite tourism and during the development of mass tourism regardless the use of ecological types of transport. "Iron curtain" and the sale of tour packages in the USSR by the directive method reasoned domestic tourists to be saturated by domestic types of tour packages and not to be satisfied by domestic tour services, which made domestic tourism not competitive and put it into decline.

\section{Methodology}

To analyze the development of the Russian tourism the statistical data of the Russian Federal Statistic Service [19] was gathered and analyzed with the help of the regression method. Due to the fact that during some period of time the statistic was gathered differently there were chosen and estimated 4 periods. Anther stage was to estimate the attitudes of Russian citizens to rural tourism. The results of Russian Public Opinion Research Center VCIOM [20] helped to understand the main attitudes to tourism at its whole and to rural tourism, in particular. 


\section{Research}

We can revise the evaluation of tourism superstructure in the Russian Federation and the USSR according to one of its main indicators, number of hotels and other tourists' establishments and its capacity (Fig. 1). We see that till the $1992^{\text {th }}$ the number of hotels and other tourists establishments had been growing steadily. But after the "perestroika" because of political and economic crisis in the country, low incomes of its citizens and the lack of governmental support the number of hotels and other tourist establishments began to fall and the process had been continuing till the 2002. And the outcomes from the governmental support of the tourism we can see only 6 years after. Only 16 years after the number of hotels and other tourists establishments arrived at its past maximum index, and to the 2016 it increased almost 4 times to its index of 1970.

The capacity of hotels

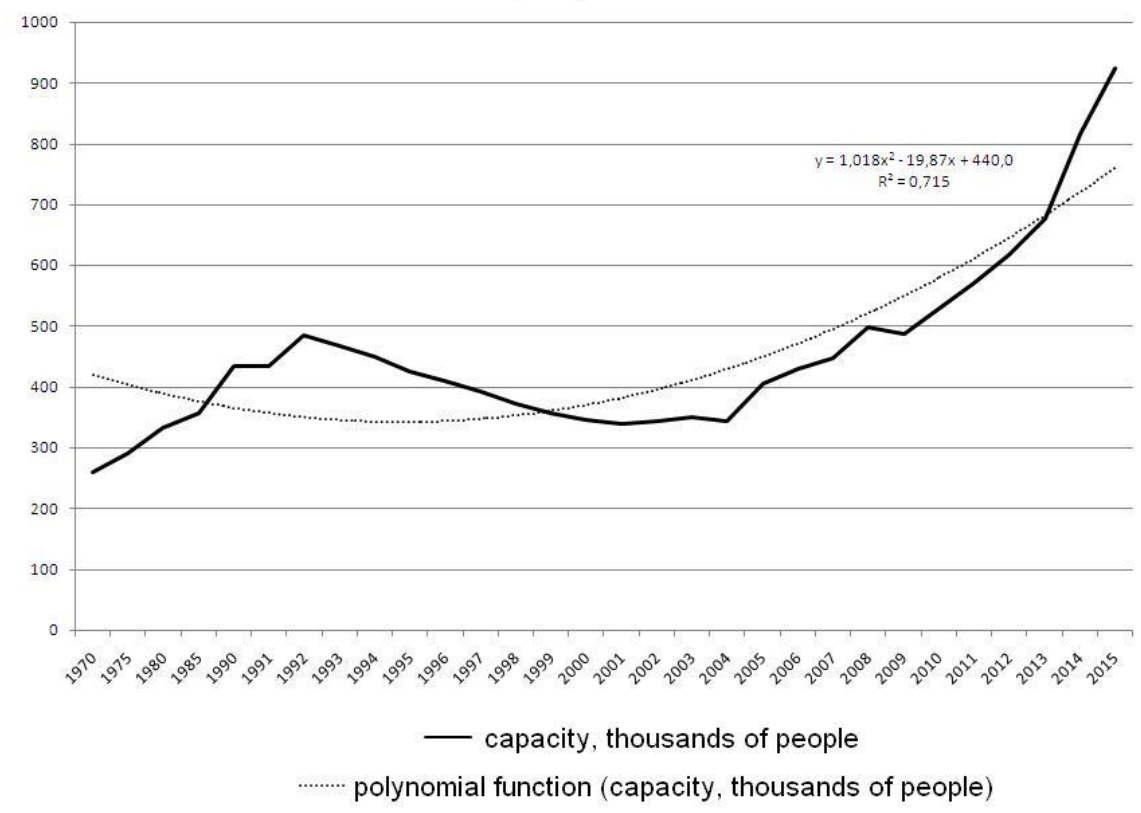

Fig. 1. Capacity of Hotel Infrastructure in the USSR and the Russian Federation, thousands of places (source: elaborated by the authors)

The capacity of hotels (Fig. 1) can be described by the following polynomial equation (1)

$$
y=1,018 x^{2}-19,87 x+440,0
$$

with the coefficient of determination as following

$$
R^{2}=0,715
$$

The number of hotels in the USSR and the Russian Federation (Fig.2) can be described by the following polynomial equation (2)

$$
y_{2}=19,03 x_{2}^{2}-399,3 x_{2}+6201
$$

with the coefficient of determination as following,

$$
R_{2}{ }^{2}=0,766
$$


Number of Hotels in the USSR and the Russian Federation

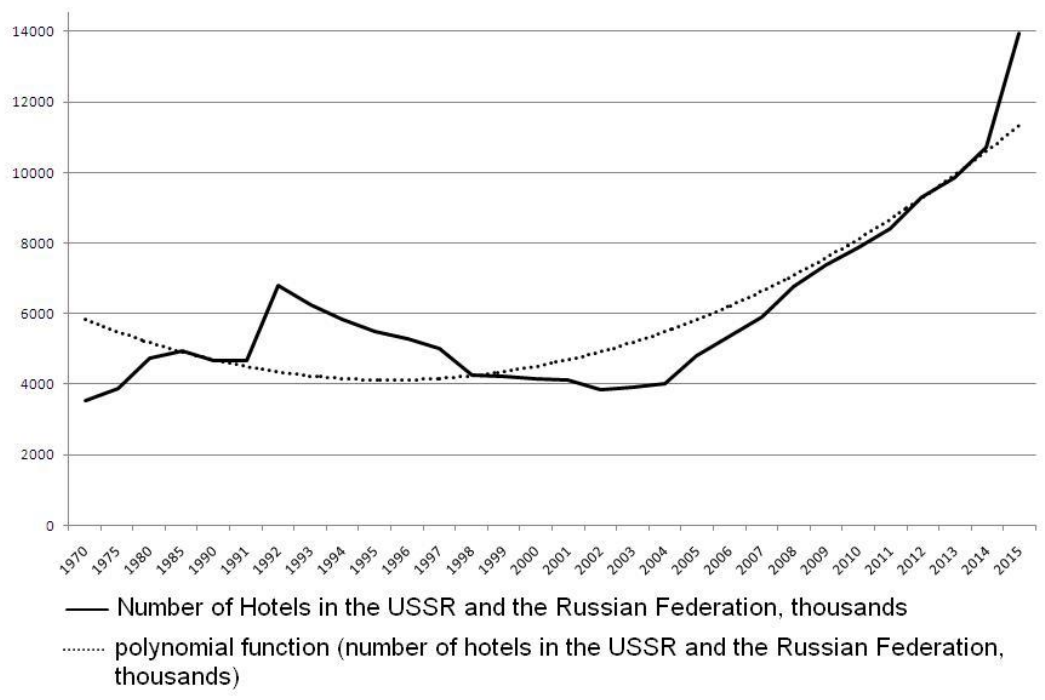

Fig 2. Number of hotels in the USSR and the Russian Federation, thousands.

We see that the coefficient of determination of the polynomial equation is not enough to be valid. According to Douglas C. Frechtling [30] the regressions methods do not give us accurate forecasts in tourism, and we need also some tests stability of any researched system. As far as we know that the Russian economic system is politically and economically unstable, especially the regional economics, the forecasting with the use of linear regression and the polynomial equation can be taken into account, but with the regard to other optional scenarios.

Exploring the equations of number of hotels in the Russian Federation (Fig. 3) during the period from 1990 to $2015^{\text {th }}$ we see that the validity criterion for the polynomial equation is higher. With the help of the following polynomial equation to forecast the raise of the number of hotels we can use the following equation (3)

$$
y_{2}=31,92 x_{2}^{2}-641,4 x_{2}+7321
$$

with the coefficient of determination as following,

$$
R_{2}^{2}=0,889
$$

Exploring the equations of number of hotels in the Russian Federation (Fig. 4) during the period from 2000 to 2015th we see that the validity criteria is much higher. At the same time, we can add that this the period when the political situation of the country was rather stable, it is characterized by the government of one president and following one strategic objective.

The forecast of the number of hotels can be described by the following polynomial equation (Equation 4).

$$
y_{2}=3,034 x_{2}^{2}-17,23 x_{2}+370,3
$$

with the coefficient of determination as following,

$$
R_{2}{ }^{2}=0,973
$$


Number of Hotels in the Russian Federation during the period 1990-2015

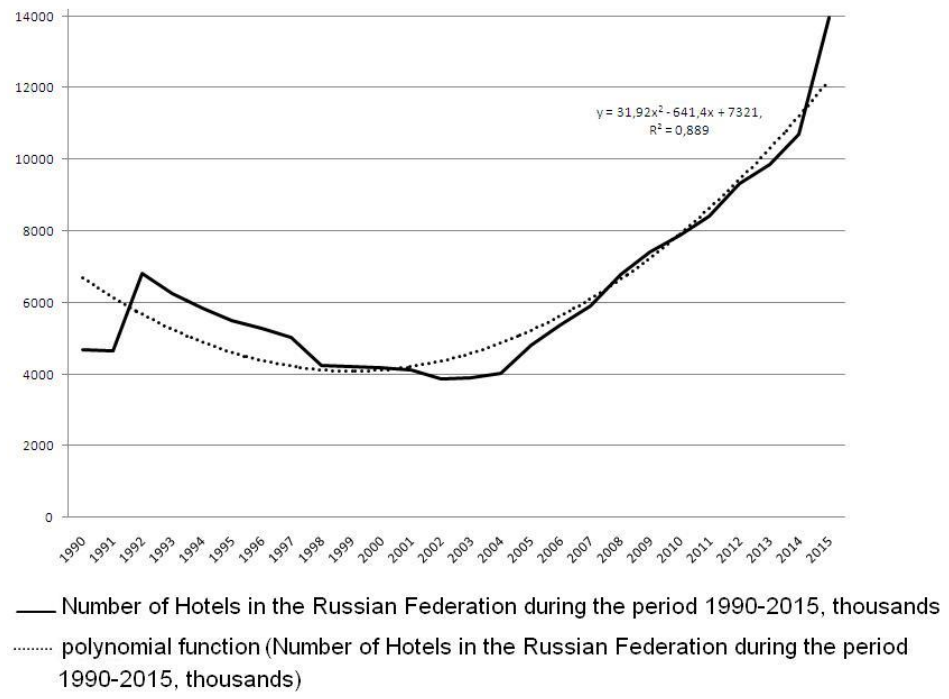

Fig. 3. Number of Hotels in the Russian Federation during the period 1990-2015, thousands

Number of Hotels in the Russian Federation during the period 2000-2015

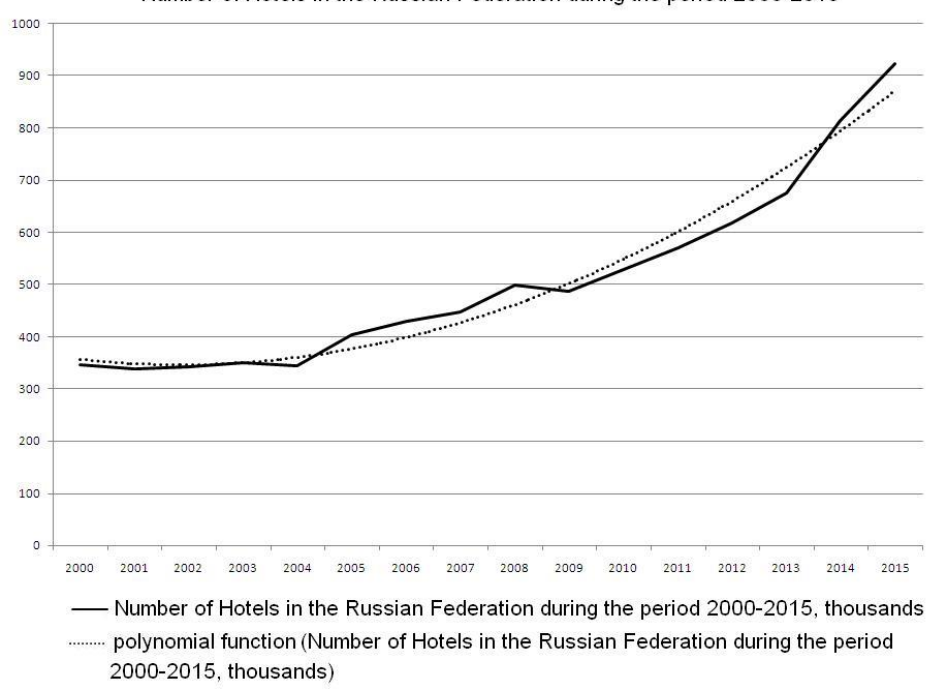

Fig. 4. Number of Hotels in the Russian Federation during the period 2000-2015, thousands.

\section{Discussion}

According to the interview, implemented by the researches of VCIOM only $7 \%$ of Russian people took their holiday outside the countries of the former Soviet Union, $3 \%$ - at other territories of the former Soviet Union and $1 \%$ - in the Baltic countries, and the rest part of interviewers took their holiday in Russia, $35 \%$ - at their dacha, $33 \%$ - just stayed at home, $17 \%$ had rest in another Russian city or a village, only $11 \%$ prefered the resorts of Krasnodarskiy Kray and $6 \%$ opted for Crimea. The tendency to take holidays within the boundaries of the country can be observed for the whole period of Russian tourism industry. It can be explained by such reasons as relatively affordable prices for domestic 
tours in comparison to outbound tour packages, visa obstacles, language bareers as well as political reasons. At the same time, according to the ITB World Travel Trends Report [21] the demand for travel to and around Russia rises from outbound tourists. According to the interview implemented by Ermakova Zh. A. \& Teteryatnik O.P. [22] the target market for rural tourism is very vide and not heterogeneous, it makes $65 \%$ of women and $35 \%$ of men, $40 \%$ of families at the age from 35 to 50 years old, the rest is the youth from 20 to 35 and the same part is for the retired.

Regarding the above mentioned thesis about tourism statistics and forecasting we can see tourist flows to NWFD during the period from 2006 to the $2016^{\text {th }}$ mentioned in the research of Aleksandrov I. \& Fedorova M. [23]. The research shows that tourist flows to the districts of NWFD are described by the polynomial equation, and the only exception is the Vologda Oblast, where inbound tourist flow can be described by the linear equation with the quiet high coefficient of determination which is 0.948 . The coefficients of determination for the polynomial equations for the rest districts of NWFD are also vary from the lowest one, which is 0.867 for Kaliningrad Oblast, to the highest one, which is 0.976, for Pskov Oblast.

\section{Conclusion}

The research was devoted to analyze whether rural tourism can be an option to produce non-importables for rural territories. NWFD was chosen as a case study due to its favorable geographical location to the most significant cities of Russia (Moscow and SaintPetersburg), its main tourist segment. The research shows that with the government support tourism possess positive scenario. For example, during the time of Soviet Union domestic tourism was supported by the government to great extent that is why till 1992 the amount of the objects of superstructure had been always rising. Nature-oriented tourism was also very popular and long-term living in the countryside and in tune with the Russian mentality. But this scenario is ensures by stable political economical situation. To make rural territories more sustainable and independent we ascertain that bottom-up development for rural territories is the most appropriate. For now, with the rising demand for self-travelling, "red tourism" [22], solo-travelling, long term travel, volunteering, rural tourism, with its concept of authenticity and creativity makes great sense to revise the strategy of developing tourism infrastructure and making it more viable in the countryside. According to the last sociological interviews rural tourism, as a type of rest, is beginning to be very popular.

\section{References}

1. V. Krutikov, O. Fedorova, V. Gvorys, Russian Journal of Entrepreneurship, 23(14), 96103 (2013)

2. M. Yu. Fedorova, The scientific journal of the State Commission for Academic Degrees and Titles «Regional problems of transforming the economy», 3, 36-43(2017) DOI:10.26726/2305-4484-2017-3-36-43

3. M.C. Hall, S.J. Page, The Geography of Tourism and Recreation: Environment, Place and Space (Routledge, London, 1999)

4. L.E. Akimova, S.K. Volkov, Regional Economy, 319, 40 (2013)

5. S.A. Levin, Bulletin of the American Mathematical Society, 40(1) 3-19 (2003)

6. R. Baggio, N. Scott, C. Cooper, Tourism Review, 65(4), 51-60 (2010) DOI $10.1108 / 16605371011093863$ 
7. R.W. Butler, Tourism Area Life Cycle. Goodfellow Publishers Limited, Woodeaton (OX3 9TJ , Oxford, 2003) URL: http://www.goodfellowpublishers.com/free_files/fileTALC.pdf

8. C. Cooper, S. Scott, R. Baggio, Anatolia: An International Journal of Tourism and Hospitality Research, 20(1), 33-45 (2009)

9. D. Stylidis, International Journal of Tourism Research, 18, 2 (2015) DOI: 10.1002/jtr.2039

10. T. Schroeder, Journal of Travel Research, 34 (4,) 71-3 (1996) DOI: $10.1177 / 004728759603400411$

11. H. Ramkissoon, R. Nunkoo, International Journal of Hopitality and Tourism Administration, 12,(2), 123-143 (2011), DOI 10.1080/15256480.2011.564493

12. V. Ya. Ahmetov, G.I. Yakshimbetova, R.Z. Yarmuhametov, e-Journal "Naukovedenie" 8(2), 1-9(2016), p. 1-9, DOI: 10.15862/89EVN216

13. T.G. Nefyodova, J. Pallot, (2006), Neizvestnoe selskoe hozyajstvo, ili Zachem nuzhna korova? [The Unknown Agriculture, or Why Do People Need a Cow?], (In Russ.), Moscow: New publishing house, 320

14. T.G. Nefyodova, World of Russia. Sociology. Ethnology, 3, 35-60 (2003)

15. M.D. Gagarsky, Geographical Bulletin, (2010)

16. Wang Z., Sustainable Governance of Rural Tourism Destination in China, A thesis submitted to Auckland University of Technology in fulfilment of the requierements for the degree of Doctor of Philosophy (PhD). School of Hospitality and Tourism Auckland University of Technology, 500, (2016) [Electronic source] http://aut.researchgateway.ac.nz/handle/10292/10179

17. N.D. Alekseeva, Vestnik of Volzhsky University after V.N. Tatischev, 3 227-36 (2012)

18. Douglas C. Frechtling, Forecasting Tourism Demand, Methods and Strategies (Routledge, London, 2010)

19. Federation Federal State Statistics Service http://www.gks.ru

20. Russian Public Opinion Research Center (VCIOM) [Electronic source] URL: https://wciom.ru/fileadmin/file/reports_conferences/2017/2017-09-20_leto.pdf

21. IPK International (2016), ITB World Travel Trends Report 2016 / 2017, Messe Berlin $\mathrm{GmbH}$, 31, [Electronic source] http://www.itbberlin.de/media/itb/itb_dl_all/itb_presse_all/World_Travel_Trends_Report_2016_2017 .pdf

22.Zh. A. Ermakova, O.P. Teteryatnik, Rural Tourism in Russia, Proceedings of the III International Forum "Rural Tourism in Russia", 111-14 http://www.rosinformagrotech.ru/sites/default/files/files/selskii_tyrizm_2014.pdf

23. I. Aleksandrov, M. Fedorova, MATEC Web of Conferences, 170, 01011 (2018),DOI: 10.1051/matecconf/201817001011 